\title{
Effect of live weight on libido, sperm quality, testosterone and luteinizing hormone in replacement stock of Ongole Grade bull
}

\author{
L. Affandhy*, H.P. Fitrayady, M. Luthfi and Y. Widyaningrum \\ ${ }^{1}$ Indonesian Beef Cattle Research Institute \\ Jalan Pahlawan Grati-Pasuruan 67184, Indonesia \\ *CorrespondingE-mail: lukmansingosari@gmail.com
}

Received October 04, 2017; Accepted November 07, 2018

\begin{abstract}
ABSTRAK
Penelitian bertujuan untuk mengetahui pengaruh bobot badan (BB) pada penampungan semen terhadap libido, hormon testosteron, luteinizing hormone (LH) dan kualitas semen pejantan sapi Peranakan Ongole (PO). Penelitian ini menggunakan 32 ekor calon pejantan sapi PO umur 20-24 bulan dengan Rancangan Acak Lengkap (RAL); dibagi menjadi empat perlakuan kelompok BB, yaitu kelompok I $(170-<210 \mathrm{~kg})$, kelompok II $(210-<250 \mathrm{~kg})$, kelompok III $(250-<290 \mathrm{~kg})$, dan kelompok IV 290-330kg. Parameter: tingkah laku libido, hormon testosteron, LH, dan kualitas semen. Data dianalisis dengan Anova. Hasil pengamatan libido pada pejantan sapi PO menunjukkan peningkatan terutama pada kelompok II dan III daripada kelompok IV, namun penurunan libido pada kelompok IV masih lebih baik daripada kelompok I. Hormon LH tertinggi dihasilkan pada kelompok IV, tetapi hormon testosteron rendah. Persentase sperma hidup terendah dihasilkan pada kelompok I $((21,25 \pm 13,20 \%)$ daripada kelompok II $(66,00 \pm 11,17 \%)$, III $(59,80 \pm 22,20 \%)$, dan IV $(75,67 \pm 9,46 \%)$. Disimpulkan bahwa libido, kualitas sperma, hormon testosteron dan LH calon pejantan sapi PO pada kelompok II, III, dan IV lebih baik dibandingkan kelompok I; sehingga disarankan standar BB sebagai pejantan minimal memiliki bobot badan $250 \mathrm{~kg}$.
\end{abstract}

Kata kunci: Sapi PO, kualitas semen, libido, bobot badan

\begin{abstract}
The objective of this study was to determine the effect of live weight (LW) on libido, sperm quality, testosterone, luteinizing hormone (LH) in Ongole grade (OG) bull. This study used 32 heads of OG bull with a completely randomized design that were divided to four different LW groups, i.e. group I was 170 to $<210 \mathrm{~kg}$, group II was 210 to $<250 \mathrm{~kg}$, group III was 250 to $<290 \mathrm{~kg}$ and group IV was 290 to $330 \mathrm{~kg}$. Parameters: observed were libido, testosterone hormone, LH, and semen quality. Data were analyzed by ANOVA. Libido of OG bull in group II and III higher than those in group IV. The testosterone hormone and LH showed that group II, III and IV were better than group I. The highest LH was in group IV, but low levels of testosterone were observed in these respective groups. Live sperm was the lowest in group I $(21.25 \pm 13,20 \%)$ than II $(66.00 \pm 11.17 \%)$, III $(59.80 \pm 22.20 \%)$ and IV $(75,67 \pm 9.46 \%)$. It can be concluded that the libido, sperm quality, testosterone, LH of OG bull in group II, III and IV were better than those in the group I, therefore standard LW of OG bulls had at least $250 \mathrm{~kg}$.
\end{abstract}

Keywords: : Ongole Grade bull, semen quality, libido, live weight 


\section{INTRODUCTION}

Beef cattle breeding as the main supplier of domestic cattle are largely a small-scale livestock breeding business, so its productivity is not profitable and can not support farmers' income. The productivity of beef cattle enterprise can be done by providing qualified bulls that have a good libido as well as their high sperm quality. This will ensure the successful gestation. The success of a pregnancy in a cow is determined by the ability of a bull to mate a cow, especially in a natural mating program or a bull used as a detector for estrus cow in an artificial insemination (AI) program. However, not all bulls can be used as detectors, only bulls that have capability to copulate the cow and produce productive semen, because the bulls have good quality of semen. Commonly, cattle breeding business applies for AI program due to the limitations of qualified bulls, even though some farmers still use natural mating by using bulls. Some smallholders used cross-breed cattleas a source of frozen semen to meet user demand in some parts of Indonesia (Affandhy et al., 2010), although the results of exotic $\mathrm{F}_{1}$ crosses of exotic bulls generally produce low semen production and ejaculation (Thippeswamy et al., 2014).

The optimal protein level in palm-based byproduct could improve semen quality and LW (Ratnawati and Affandhy, 2013). However, if there is a decrease in LW, BCS and exercise would not affect semen quality (Ratnawati et al., 2015). Libido levels Ongole-cross breed males in loose housing were better than those placed in individual housings (Luthfi et al., 2015). The increase of LW and BCS can increase the volume of semen, as well as the size of the scrotum that can improve the quality of semen (Kastelic et al., 2001). So it is necessary to study the characteristics of semen collected by grouping LW.

Housing bulls with heifers/cows will enable them to reach puberty at a young age (Luthfi, 2015). Group housing management in young bulls can increase the production of testosterone for puberty acceleration (Widyaningrum et al., 2015). Testosterone improves libido and is able to increase erection and ejaculation of bulls. Libido affects the quality and quantity of semen, and libido is influenced by the secretion of testosterone produced by the testes (Toelihere, 1985). Poor quality handling also can cause low libido, sperm quality, and triggers (Partodiharjo, 1987). Other factors such as the age of the bulls (Zhan-Xing et al., 2014; Farooq et al., 2013), collection technique (i.e. transrectal massage and ejaculator) (Ali, 2014; Sylla et al., 2015; Palmer et al., 2015), environmental temperature, collection, seasons, management (Rasyid et al., 2003; Bhakat et al., 2009; Al-Badry, 2013; Chacur et al., 2013, Farooq et al., 2013) and the concentrations of hormones (GhRh, LH and testosterone) (Masoumi et al., 2011; Chacur et al.,2013) decrease libido and sperm quality. Research needs to be done to improve libido and sperm quality, such as regular sperm collection and improving LW. The objective of this study was to determine the effect of live weight (LW) on libido, sperm quality, testosterone, luteinizing hormone (LH) in OG bull.

\section{MATERIALS AND METHODS}

Thirty-two heads of Ongole grade (OG) bulls were used in this study, 20-24 months old; which were divided into four different live weight (LW) groups housed in the group model housing, i.e. group I was 170 to $<210 \mathrm{~kg}(208.63 \pm 13.03 \mathrm{~kg})$, group II was 210 to $<250 \mathrm{~kg}(247.00 \pm 17.72 \mathrm{~kg})$, group III was 250 to $<290 \mathrm{~kg}(282.88 \pm 12.39 \mathrm{~kg})$, and group IV was 290 to $330 \mathrm{~kg}(317.86 \pm 17.11$ $\mathrm{kg}$ ). The semen collection was conducted once a week for five months by bringing the bulls to the teaser (cow or bull) and trained to be able to ride the teaser for 10 minutes.

Each group contained 4 (four) bulls in a housing size of 3-4 $\mathrm{m}^{2}$ per animal. The bamboo was used to separate treatment groups. The feed was given to all groups about $\geq 3 \%$ dry matter $(\mathrm{DM})$ of $\mathrm{LW}$ containing $\geq 8 \%$ crude protein $(\mathrm{CP})$. Feed composition and nutritien content are presented in Table 1.

\section{Testosterone and LH Analysis}

Blood collections were done through a jugular vein using a needle and inject tube, and then the blood was centrifuged at $1.500 \mathrm{rpm}$. The blood serum was inserted in Eppendorf and stored temporarily in the freezer until the blood serum was analyzed. The analysis of testosterone and LH hormones used the Bovine Blood Serum Kit and the Elisa Test using Kit of DRG Gmbh Germany at Endocrine of Reproduction Departement Laboratory of the Faculty of the Veterinary of Airlangga University. Blood was sampled in the morning at the initial, middle and 
Table 1. Feed Composition and Nutrient Content of the Ration in this Study

\begin{tabular}{lccc}
\hline & Fresh (kg/head/day) & DM (kg/head/day) & CP (gram/head/day) \\
\hline Live Weight Group I \& II* & & & \\
Elephant grass & 10.75 & 2.04 & 122.55 \\
Commercial Concentrate & 5.55 & 4.77 & 286.38 \\
Glyricidea maculata & 1.70 & 0.58 & 75.14 \\
Rice straw & 5.00 & 3.60 & 180.00 \\
Amount & 5.75 & - & - \\
Live Weight Group III \& IV** & & & 153.90 \\
Elephant grass & 13.52 & 2.56 & 397.32 \\
Commercial Concentrate & 7.70 & 6.62 & 79.56 \\
Glyricidea maculata & 1.80 & 0.61 & 180.00 \\
Rice straw & 5.00 & 3.60 & - \\
Amount & 5.60 & - & \\
*: Group I was 170 to $<210 \mathrm{~kg}(208.63 \pm 13.03 \mathrm{~kg})$, Group II was 210 to $<250 \mathrm{~kg}(247.00 \pm 17.72 \mathrm{~kg})$ \\
**: Group III 250 to $<290 \mathrm{~kg}(282.88 \pm 12.39 \mathrm{~kg})$, and Group IV was 290 to $330 \mathrm{~kg}(317.86 \pm 17.11 \mathrm{~kg})$
\end{tabular}

end of the study.

\section{Analysis of Semen Quality and Libido Test}

The analysis of semen quality and libido test were performed at the initial, middle and end of the study. The initial observation was in the second week after the training pre-experimental period; middle observation was at week 12 after training and the end observation at 24 weeks after training. Electro-ejaculatory was used to collect semen.

Analysis of quality and volume of semen using a set of reproduction test equipment (artificial vagina, sperm analysis, hemocytometer, $\mathrm{pH}$ paper, and microscope) and some other laboratory equipment (water bath, measuring glass, object glass, cover glass, and so on). The libido behavior test was performed simultaneously with the semen collection for 10 minutes. Animal behavior measurements were tested using a non-parametric statistical system, i.e. the value of +++ (kissing, mounting/up, and penis out); value ++ (kiss and penis out); and value + (smell) and value - (no response at all) (Luthfi, 2015).

\section{Parameter and Data Analysis}

The parameters observed were testosterone hormone, LH, and libido for 24 hours at the end of the study, including (mounting and penis discharge). The data were analyzed as a Completely Randomized Design based on four different LW group at the initial, middle and end of the study using ANOVA (Cowan, 1998).

\section{RESULTS AND DISCUSSION}

\section{Libido}

The libido of OG replacement stock bull in group II and III was better than those in group I and IV. The low libido in the group IV (Table 2) was caused by low concentrations of testosterone and high concentration of LH hormone. The decrease or low of libido and testosterone concentrationwas still in a normal range. This was because cattle still can mount other with the score at the end of the study showed scoring ++. Thus, the bull having $\mathrm{LW}$ of $250 \mathrm{~kg}$ has enough libido and testosterone levels, but it has low LH concentration that can affect sperm quality. This was supported by Luthfi (2015) who also found that libido behavior (i.e sniffing, licking and mounting) and sperm quality of bulls were affected by LW. The LW of $<216 \mathrm{~kg}$ caused low libido and low sperm quality.This was in line with Tillman et al., (1998) who also reported that the minimum LW of bulls should be 235 to $292 \mathrm{~kg}$ to be able to produce sperm. Thus libido is strongly influenced by the training and LW, which is at least $250 \mathrm{~kg}$ for the replacement stock bull. Other 
Table 2. The Libido Score of Ongole Grade Bull based on Live Weight Group

\begin{tabular}{lccccc}
\hline \multirow{2}{*}{ Parameters } & \multicolumn{4}{c}{ Live Weight Groups } \\
\cline { 2 - 5 } & I & II & III & IV \\
\hline Initial libido score & + & + & + & + \\
Middle libido score & + & ++ & ++ & +++ \\
Final libido score: & + & +++ & +++ & ++ \\
\hline
\end{tabular}

+++ (kissing, mounting / up, and penis out); ++ (kiss and penis out); + (smell) and - (no response at all).

factors that can cause low libido or sperm quality include handling that caused stress in bulls (Partodihardjo, 1987), age of bull (Zhan-Xing et al., 2014), semen collection techniques such as transrectal massage and electro-ejaculatory (Ali, 2014; Sylla et al., 2015; Palmer et al., 2015), environmental temperature, season and management (Rasyid et al., 2003; Bhakat et al., 2009; Al-Badry, 2013).

\section{Profile of Testosterone and LH Hrmones}

The concentration of testosterone and $\mathrm{LH}$ hormone in group II, III and IV were better than those in the group I. The highest LH hormone was produced in group IV, but the group In produced low testosterone concentration (Table 3 ).

The high LH hormone in the group IV results from stimulation of the hypothalamus to produce gonadotropin realizing hormone $(\mathrm{GnRH})$, which will stimulate adenohipofisa to produce follicle stimulating hormone (FSH) and at that time produced testosterone by the testes. Ramaswamy and Weinbauer (2014) reported that $\mathrm{LH}$, testosterone, and FSH are the pivotal endocrine factors controlling testicular functions. While the relative importance of either hormone appears somewhat different between rodents and primates, generally, however, both LH/testosterone and FSH are necessary for quantitatively normal spermatogenesis, at least in non-seasonal species. Borg et al. (1991) found no significant alterationsin testosterone levels associated with sexual behavior, although values were different for Angus bulls with different reproductive behavior performanceand different age (Sekoni et al., 2010; Rajak et al., 2014). As a result of increase concentrations of LH hormone leads to decrease testosterone hormone concentration in group IV that could ultimately lead to low libido behavior of group II and III (Table 2). Although libido of group of IVwas low because of low concentration of testosterone hormone, but it is still within normal limits (Mahmood et al., 2013), so the quality of sperm in group IV is still better than group I. More ever Chacur et al. (2013) reported that the concentration of hormones and sperm quality vary throughout the year. Testosterone secretion will show higher concentrations during the early stages of animal growth (Gulia et al., 2010) among those occurring in Groups I, II and III (Table 3). The concentration of testosterone in this study was similar to those in previous researches. Widyaningrum et al. (2015) reported that Ongole cross breed bulls, had $6.13 \mathrm{ng} / \mathrm{ml}$ of testosterone and $6.14 \mathrm{ng} / \mathrm{ml}$ of $\mathrm{LH}$ at housing group, while Syarifudin et al. (2017) stated that the testosterone level of Bali bulls at individual pens were between 4.57 to $4.79 \mathrm{ng} / \mathrm{ml}$ at 06.00 in the morning. In addition to increasing libido, testosterone also affects the ability of males for erection and ejaculation. Libido affects the quality and quantity of semen, while libido is influenced by the secretion of testosterone produced by the testes (Toelihere, 1985). It is also supported by some research results that the concentration of hormones $\mathrm{GnRH}, \mathrm{LH}$, testosterone and other reproductive hormones such as RBST may affect libido and sperm quality (El-Khawaga et al., 2011; Masoumi et al., 2011; and Hakim et al., 2016).

\section{Quantity and Quality of Semen}

At the beginning of the study, volume and quality of semen were testedin all $\mathrm{OG}$ replacement stocks, but at the initial and middle of the study, collected only two animals could be collected, i.e. Group III and IV. It resulted in less dense liquid semen. Therefore, at the end of the study, electro-ejaculator was used (Table 4 and Table 5). 


\section{Volume, pH, color consistency}

Group I had the lowest volume and sperm concentration among other groups as well as having the clearest color (Table 4). This is because the group I seemed to be less than $250 \mathrm{~kg}$. The $\mathrm{pH}$ of all LW groups shows no difference, even the $\mathrm{pH}$ value indicates acidity of the base $(>7)$, but the $\mathrm{pH}$ value did not affect the quality of semen (color, consistency, life sperm and mass movement) (Table 4). The high $\mathrm{pH}$ values in all groups were due to the use of the electroejaculatory equipment so that all of the semen fluids came out. Sperm collection using transrectal massage (Ali, 2014) and electro- ejaculator techniques (Sylla et al., 2015). Palmer et al. (2015) obtained acidity ( $\mathrm{pH} 8.2 \pm 0.3$ ). The $\mathrm{pH}$ of semen collected using electro-ejaculators was ranging from 7 to 8 and there was no side effects of using that electro-ejaculator (Haron et al., 2000). Group I had the lowest semen volume. This was because, at the end of the current study, the LW of this group was less than $250 \mathrm{~kg}$. This might affect the imperfect spermatogenesis process that affected the color of semen (clear) and consistency (dilute). Therefore, sperm concentration in group I was the lowest among others (Table 5).

It appears the average sperm concentration,

Table 3. The Profile of Testosterone and LH Hormones in Ongole Grade Bull based on the Live Weight Group

\begin{tabular}{llllll}
\hline \multirow{2}{*}{ Parameters } & \multicolumn{4}{c}{ Live Weight Groups } \\
\cline { 2 - 5 } & & I & II & III & IV \\
\hline
\end{tabular}

Testosterone Hormone (ng/ml)

$\begin{array}{cllll}\text { Initial of study } & 3.46 \pm 1.68 & 6.62 \pm 2.92 & 5.48 \pm 2.71 & 6.61 \pm 2.20 \\ \text { Middle of study } & 5.86 \pm 2.82 & 8.15 \pm 2.78 & 6.07 \pm 2.09 & 3.74 \pm 3.35 \\ \text { Final of study } & 7.92 \pm 2.24^{\mathrm{b}} & 8.35 \pm 2.96^{\mathrm{b}} & 7.07 \pm 2.17^{\mathrm{b}} & 4.81 \pm 1.91^{\mathrm{a}} \\ \text { LH hormone (ng/ml) } & & & & \\ \text { Initial of study } & 1.32 \pm 0.00 & 0.68 \pm 0.58 & 1.12 \pm 1.12 & 2.02 \pm 1.32 \\ \text { Middle of study } & 0.50 \pm 0.00 & 0.95 \pm 0.45 & 3.00 \pm 1.69 & 2.75 \pm 3.81 \\ \text { Final of Study } & 1.24 \pm 0.53^{\mathrm{a}} & 2.42 \pm 1.61^{\mathrm{a}} & 2.01 \pm 1.93^{\mathrm{a}} & 8.51 \pm 6.92^{\mathrm{b}}\end{array}$

$\mathrm{a}, \mathrm{b}$ different superscripts on the same row indicates significantly different $(\mathrm{P}<0.05)$

Table 4. Volume, pH, Color and Consistency of Ongole Grade Bull by Live Weight Group at the End of the Study

\begin{tabular}{lcccc}
\hline \multirow{2}{*}{\multicolumn{1}{c}{ Parameters }} & \multicolumn{4}{c}{ Live Weight Groups } \\
\cline { 2 - 5 } & I & II & III & IV \\
\hline Volume semen $(\mathrm{mL})$ & $1.95 \pm 1.12^{\mathrm{a}}$ & $3.54 \pm 1.90^{\mathrm{a}}$ & $3.40 \pm 1.48^{\mathrm{a}}$ & $4.94 \pm 2.83^{\mathrm{b}}$ \\
pH semen & $8.44 \pm 1.21$ & $7.75 \pm 0.76$ & $7.75 \pm 0.27$ & $8.50 \pm 1.31$ \\
Color of semen & clear & clear-white milk & clear-white milk & clear-white milk \\
Consistency of semen & diluter & medium-watered & medium-watered & medium-watered \\
\hline
\end{tabular}

${ }^{a b}$ different superscripts on somerow indicates significantly different $(\mathrm{P}<0.05)$ 
live percentage and mass sperm in group II, III and IV show better value compared to group I, but the sperm concentration value was still less when it will be used for frozen semen (Table 5). The standard sperm concentration used for frozen semen was at least 500-1000 million $/ \mathrm{ml}$ and the percentage of live sperm was $>70 \%$ (Situmorang, 2003; Affandhy, 2003), but the quality of the semen can still be used as a source of semen for mating naturally. In natural mating, although the quality of sperm is low or medium, if still able to fertilize the cows.

Sperm concentration in group I, II, III, and IV appears lower and below the standard for being used of frozen semen, but it still can be used for natural mating because the ages were still less than three years old; This was similar to that of Igna et al. (2010) research that the highest value of spermatozoa concentration per ejaculate in bulls was between 5-7 years old. This is similar to that reported by Zhan - Xing et al. (2014), reporting that the age of Java bulls influences the semen volume. Age influences the volume of semen the highest volume was at the age of $>3$ years old.

\section{Feed Intake}

The results showed that bulls at $250-330 \mathrm{~kg}$ had high CP intake (Table 6). These results were in areeement with (Kearl, 1982) who also reported that increasing $0.6-7 \mathrm{~kg} / \mathrm{head} /$ day required 623 $679 \mathrm{~g} / \mathrm{head} /$ day CP. As a consequence, bulls exhibited high libido (Table 2).

The research on improving the management of beef cattle in Jambi showed that the feeding of palm-based waste with $12 \%$ protein level in bulls, can improve the quality of semen and the development of LW (Ratnawati and Affandhy, 2013). However, that exercise has no effectingon increasing a semen quality at OG bull, if it is decreasing on $\mathrm{LW}, \mathrm{BCS}$, and $\mathrm{ADG}$ with on $11,2 \%$ $\mathrm{CP}$ feed and there are decrease on DM intake was $3.4 \mathrm{~kg} /$ day (Ratnawati et al., 2015). The inactive bulls secreted less LH and testosterone that are responsible for increasing libido, erectionand ejaculation. Libido influential be compared with LW I $(170$ to $<210 \mathrm{~kg})$, so it is recommended that the $\mathrm{LW}$ as a minimum of $250 \mathrm{~kg} \mathrm{LW}$ of a

Table 5. Concentrations, Live Sperm Percentage and Sperm Massa Movement of Ongole Grade Bull by Group

\begin{tabular}{lcccc}
\hline Parameters & \multicolumn{4}{c}{ Live Weight Groups } \\
\cline { 2 - 5 } & I & II & III & IV \\
\hline $\begin{array}{l}\text { Sperm Concentration } \\
\left(10^{6} / \mathrm{ml}\right)\end{array}$ & $92.50 \pm 92.51^{\mathrm{a}}$ & $300.00 \pm 156.46^{\mathrm{b}}$ & $568.00 \pm 545.13^{\mathrm{b}}$ & $370.00 \pm 310.05^{\mathrm{b}}$ \\
Live sperm (\%) & $21.25 \pm 13.20^{\mathrm{a}}$ & $66.00 \pm 11.17^{\mathrm{b}}$ & $59.80 \pm 22.20^{\mathrm{b}}$ & $75.67 \pm 9.46^{\mathrm{b}}$ \\
$\begin{array}{l}\text { Sperm massa } \\
\text { movement }\end{array}$ & + & ++ & ++ & ++ \\
\hline
\end{tabular}

${ }^{\mathrm{ab}}$ Different superscripts on the same row shows significantly different $(\mathrm{p}<0.05) .-=$ no was activity; $+=$ slow wave motion; $++=$ rapid wave motion with formation of eddies at the end of waves; and $+++=$ eddies

Table 6. The Dry Matter (DM) and Crude Protein (CP) intake of Ongole Grade Bull during the Study

\begin{tabular}{lcccc}
\hline \multirow{2}{*}{ Feed Intake } & \multicolumn{4}{c}{ Live Weight Groups } \\
\cline { 2 - 5 } & I & II & III & IV \\
\hline DM intake (kg/head) & $8.62 \pm 0.66$ & $10.77 \pm 0.76$ & $9.97 \pm 0.89$ & $12.47 \pm 1.40$ \\
CP intake (g/head) & $536.46 \pm 35.94$ & $643.96 \pm 45.45$ & $619.32 \pm 54.50$ & $754.21 \pm 72.83$ \\
\hline
\end{tabular}

$\mathrm{DM}=$ Dry Matter, $\mathrm{CP}=$ Crude Protein 
collecting with a semen collect training.

\section{CONCLUSION}

It was concluded that to be able to produce a high quality of sperm, libido, testosterone, and LH of OG bulls, at least $250 \mathrm{~kg}$ of LW should be achieved.

\section{ACKNOWLEDGMENTS}

Thank you to the technical staff of the Indonesian Beef Cattle Research Institute (DyahTuwi Ramsiati, Nur Salam, Dadang Karnadi and M. Chanafi) and Faculty of Veterinary of Airlangga University (Deceased of Prof. Dr. Ir. Laba Mahaputra, M. Sc) and Mr. M. Bahrudin) who have assisted in conducting this research.

\section{REFERENCES}

Affandhy, L. 2003. Pengaruh penambahaan choresterol dan kuning telur di dalam bahan pengencer tris-sitrat dan air kelapa muda terhadap kualitas semen cair sapi potong. Pros. Semnas Puslitbang Peternakan. Bogor, 28-29 September 2003. P. 77-84.

Affandhy, L. A. Rasyid and N.H. Krishna. 2010. Pengaruh perbaikan manajemen pemeliharaan pedet sapi potong terhadap kinerja reproduksi induk pasca beranak: studi kasus pada sapi induk PO di usaha ternak rakyat Kab. Pati Jawa Tengah. Pros. Semnas. Teknologi Peternakan dan Veteriner. Puslitbang Peternakan. Bogor, 3-4 August 2010. P. 40-46.

Ali, M. 2014. The quality of semen collected by transrectal massage in bulls restrained in the presence of a cow. Int. J. Dev. Res. 4(10): 2097-2099.

Al-Badry, K. I. 2013. Monthly changes in libido and semen characteristics for Holstein bulls born in Iraq of different reproductive efficiencies. Global. J.Bio-Sci.Bio-Techol. 2 (1):67-74.

Bhakat, M., T.K. Mohanty, A.K. Gupta and V.S. Raina. 2009. Effect of season and management on semen quality of breeding bulls- a review. Agric. Rev. 30 (2):79-93.

Borg, K.E.,K.L. Esbenshade and B.H. Johnson. 1991. Cortisol, growth hormone, and testosterone concentrations during mating behavior in the bull and boar. J. Anim. Sci.
69:3230-3240.

Chacur, M.G.M., K.T.Mizusaki and L.R.A.G. Filho. 2013. Seasonal effects on semen and testosterone in Zebu and Taurine bulls. Acta Sci. Vet. 41:1-5.

El-Khawaga, A.R.M., M.M.M. Kandiel, G.A. Sosa, M.E.A.A. El- Roos, A.E. AbdelGhaffar and A.E.I. El-Salam. 2011. Effect of GnRH analog on libido and semen characteristics of pubertal buffalo bulls. Benha Vet. Med. J. (1):28-34.

Farooq, U., A. Ijaz, N. Ahmad, H. Rehman and H. Zaneb. 2013. Investigations on semen quality and freezability of Cholistani breeding bulls - a preliminary study from Cholistan Desert of Pakistan. J. Anim. Plant. Sci. 23(2): 359-363.

Gulia, S., M. Sarkar, V. Kumar, H.H.D.Meyer and B.S. Prakash. 2010. Divergent development of testosterone secretion in male zebu (Bosindicus) and crossbred cattle (Bosindicus $\mathrm{x}$ Bostaurus) and buffaloes (Bubalus bubalis) during growth. Trop. Anim. Health Prod. 42:1143-1148.

Hakim, S., M. Zubair, M. Ahmad, S.T. Gull, A. Murtazaand S. Umar. 2016. Effect of recombinant bovine somatotropin on libido, pre, and post freezing semen parameters in Cholistani bulls.Int. J. Livest. Res. 6(4):6572.

Haron, A.W., Y. Ming and Z.Z. Zainuddin. 2000. Evaluation of semen collected by electro ejaculation from captive lesser Malay Chevrotain (Tragulusjavanicus). J. Zoo Wild. Med. 31 (2):164-167.

Cowan, G.1998.Statistical Data Analysis.Oxford University Press Inc.New York.

Igna, V., A. Moje, C. Mircu, M. Roman, C. Ghiurca, Delia Casalean and H. Cernescu. 2010. The Influence of some environmental factors and age on semen production of Fleckvieh Bulls. Lucrări Stiinłifice Med.Vet. XLIII (2):56-63.

Kastelic, J.P., R.B. Cook, R.A. Pierson and G.H. Coulter. 2001. Relationships among scrotal and testicular characteristics, sperm production, and seminal quality in 129 beef bulls. Can. J. Vet. Res. 65 (2):111-115.

Kearl, L.C. 1982. Nutrient Requirements of Ruminants in Developing Countries. International Feed Stuffs Institute. Utah Agriculture Experimental Station. Utah State Univ. Logan, Utah USA. P. 45-58. 
Luthfi, M. 2015. Respon reproduksi calon pejantan sapi PO yang dipelihara dalam kelompok sex dan model kandang yang berbeda. Thesis. Brawijaya University, Malang. Indonesia.

Luthfi, M., Y. Widyaningrum dan L. Affandhy. 2015. Tampilan pubertas sapi PO jantan muda pada pengelolaan kandang yang berbeda. Pros. Semnas Teknologi Peternakan dan Veteriner Puslitbang Peternakan, Jakarta, 8-9 October 2015. P 66-73.

Mahmood, S.A., A. Ijaz, N. Ahmad, H.U. Rehman, H. Zaneb and U. Farooq. 2013. Studies on libido and serum testosterone concentration of Cholistani AI bulls under stress-free and stressful seasons. J. Anim. Plant Sci. 23(6):1491-1495.

Masoumi, R., A.Towhidi, A.N. Javaremi, H. Nabizadeh and M. Zhandi. 2011. Influence of PGF $2 \alpha$ on semen quality and libido in Holstein bulls. Turk. J. Vet. Anim. Sci.35(1): 1-6.

Palmer CW, L.F. Brito, A.A. Arteaga, L. Söderquist, Y. Persson and A.D. Barth. 2005. Comparison of electroejaculation and transrectal massage for semen collection in range and yearling feedlot beef bulls. Anim. Reprod. Sci. 87(1-2):25-31.

Partodihardjo, S. 1987. Ilmu Reproduksi Hewan. Cetakan ke 2. CV. Mutiara Sumber Widya. Jakarta.

Rajak, S.K., A. Kumarsen, M. K. Gaurav, S.S. Layek and T.K. Mohanty. 2014 Testicular cell indices and peripheral blood testosterone concentrations in relation to age and semen quality in the crossbreed (Holstein Friesian X Tharparka Bulls). Asian-Australasian. J. Anim. Sci. 27 (11): 1554-1561.

Rasyid, A., L. Affandhy and D. B. Wijono. 2003. Profil hormon testosteron dan kualitas semen sapi pejantan Peranakan Ongole dan silangan Simmental. Pros. Pros. Semnas Teknologi Peternakan dan Veteriner. Pusat Penelitian dan Pengembangan Peternakan. Badan Penelitian dan Pengembangan Pertanian, Departemen Pertanian. Bogor, 29 - 30 September 200. P. 85-90.

Ratnawati, D and L. Affandhy. 2013. Performans reproduksi sapi jantan dengan pakan berbasis limbah sawit. Prosiding Seminar Nasional. Teknologi Peternakan dan Veteriner. Pusalitbangnak. Medan, 3-5
September 2013: 49-52.

Ratnawati, D., Y. Widyaningrum and T.A. Sulistya. 2015. Perlakuan exercise pada sapi jantan PO terhadap peningkatan kualitas semen. Pros. Seminar Nasional Teknologi Peternakan dan Veteriner Puslitbang Peternakan, Jakarta, 8-9 October 2015. P. $81-87$.

Ramaswamy, S and G.F. Weinbauer. 2014. Endocrine control of spermatogenesis: Role of $\mathrm{FSH}$ and $\mathrm{LH} /$ testosterone. Spermatogenesis 4 (2) :1-15

Sekoni, V.O., P.I. Rekwet, E.K. Bawaand P.P. Barje. 2010. Effect of age and time of sampling on semen testosterone and spermiogram of Bunaji and N'Dama Bulls. Res. J. Vet. Sci. 3(1):62-67.

Situmorang, P. 2003. Prospek penggunaan semen dingin (chilled semen) dalam usaha meningkatkan produksi sapi perah. Wartazoa 13 (1):1-7.

Sylla, L., C. Palombi, G. Stradaioli, A. Vagniluca and M. Monaci. 2015. Effect of semen collection by transrectal massage of accessory sexual glands or artificial vagina on the outcome of breeding soundness examinations of Italian yearling beef bulls. Theriogenology. 83(5):779-785.

Syarifuddin. N.A., A.L. Toleng, D.P. Rahardja, Ismartoyo and M. Yusuf. 2017. Improving libido and sperm quality of Bali bulls by supplementation of Moringa oleifera leave. Media Peternakan. 40(2) :88-93.

Thippeswamy, V.B., S.S. Layek, A. Kumaresan, T.K. Mohanty, A.K. Gupta, A.K. Chakravarty, A. Manumaran, S. Prasad. 2014. Effects of pedigree and exotic genetic inheritance of semen production traits of dairy bulls. Asian Pac. J. Reprod. 3(1):1317.

Tillman, A. D., H. Hartadi, S. Reksohadiprodjo, S. Prawirokusumo dan S. Lebdosoekodjo. 1998. Ilmu Makanan Ternak Dasar. Cetakan ke-4. Gadjah Mada University. Press, Jogyakarta.

Toelihere, M.R. 1985. Fisiologi Reproduksi pada Ternak. Penerbit Angkasa, Bandung.

Widyaningrum, Y., M. Luthfi dan L. Affandhy. 2015. Profil hormon testosteron dan LH pada sapi PO jantan muda pada model kandang yang berbeda terhadap percepatan pubertas. Pros. Semnas Teknologi Peternakan dan Veteriner Puslitbang Peternakan. Jakarta 8-9 October 2015. P. 53- 
58.

Zhan-Xing. H., H. Mei-Fen.,W. An-Kui., Z. JiCai., Z.Gang., Y. Xi-Ping., Q. Kai-Xing and H. Bi-Zhi.2014. Patterns of plasma hormone concentrations in Mithun bulls under a semi - management. J. Anim Vet. Adv. 13(12): 732-739. 